\title{
MAXIMIZING IRRIGATION WATER USE EFFICIENCY AND RICE PRODUCTIVITY BY APPLLYING A NEW TRANSPLANTING METHOD AND BEST IRRIGATION WATER MANAGEMENT
}

\author{
Hamdy M. Nasr, Salah E. El-Amir, Yosry I. Atta* and Emad F. Moustafa**
}

Soils Dept., Fac. of Agric., Cairo University, Egypt.

* Water Management and Irrigation Methods Res. Inst., Kanater Al-Khairea, Egypt.

** Irrigation Advisory Services Directorate, Ministry of Water Resources and Irrigation, El-Fayoum, Egypt.

\section{ABSTRACT:}

Rice (Oryza sativa. $L$ ) is considered one of the most important food crops, as it is a more profitable one than the other summer crops from the economical point of view in Egypt. Also, it is not only stable food source for majority of the Egyptian population but also it has become one of the most exportable crops in Egyptian agricultural system after the free cropping pattern policy. For these reasons, the areas cultivated with rice have been annually increased, although it is one of the most inefficient in water use among field crops due to it grows generally under continuously submerged conditions. Under the key of saving water conditions and achieving high water use efficiency, a special attention was focused to optimize transplanting method and irrigation water management for raising the water use efficiency of rice plants through a proper their equitably distribution among all rice fields. Thus, the problem is how to distribute the irrigation water equitably among all rice fields with high water use efficiency?

To achieve a profitable solution for this problem, a field experiment was conducted on a sandy clay loam soil during two successive growing summer seasons 2007 and 2008 at a private farm, Sinnuris district, Fayoum governorate, Egypt to evaluate the effect of applying a new method (M) for rice transplanting (transplanting on strips) on rice yield and its components as well as some soilwater relationships. However, rice seedlings of two rice cultivars of Hybrid 2 and Sakha 104 were transplanting at furrow bottoms of either $60 \mathrm{~cm}\left(\mathrm{M}_{2}\right)$ or $80 \mathrm{~cm}$ $\left(\mathrm{M}_{3}\right)$ apart as compared with the traditional transplanting method $\left(\mathrm{M}_{1}\right.$, transplanting on a flat soil), under different submerged irrigation water depths of $6 \mathrm{~cm}\left(\mathrm{D}_{1}\right)$ and $8 \mathrm{~cm}\left(\mathrm{D}_{2}\right)$.

The obtained data indicate that highly significant differences were existed among the studied transplanting methods, among some plant parameters of growth (i.e., plant height) and rice yield (i.e., panicle length, 1000 grain weight, grain and straw yields). These differences are confirmed by the mean values in combined analysis for the plant heights which recorded 100.30, 105.18 and $107.12 \mathrm{~cm}$ for $\mathrm{M}_{1}, \mathrm{M}_{2}$ and $\mathrm{M}_{3}$ treatments, respectively. Also, the tallest rice plants were significantly affected by both rice cultivars and submerged irrigation water depths, where plant height was recorded $107.1 \mathrm{~cm}$ at a depth of $8 \mathrm{~cm}\left(\mathrm{D}_{2}\right)$ for Hybrid 2 cultivar as compared with Sakha 104 which was $101.3 \mathrm{~cm}$ as an average of the two growing seasons.

Results showed also a significantly increase in panicle length due applying the new transplanting method, where its mean value in combined analysis were $19.56,20.93$ and $21.71 \mathrm{~cm}$ for $\mathrm{M}_{1}, \mathrm{M}_{2}$ and $\mathrm{M}_{3}$, with a superiority for $\mathrm{D}_{2}(8 \mathrm{~cm}$ depth) and Hybrid 2 cultivar as compared with $\mathrm{D}_{1}(6 \mathrm{~cm})$ and Sakha 104, respectively. Also, the corresponding mean values were 26.13, 28.71 and 29.25 gm for 1000 grain weight of rice vs 26.53 and 29.53 gm for submerged irrigation water depths of $D_{1}(6 \mathrm{~cm})$ and $D_{2}(8 \mathrm{~cm})$, respectively.

Fayoum J. Agric. Res. \& Dev., Vol.24, No.2, July, 2010 
As for the rice grain yield as affected by rice cultivars, transplanting methods, submerged irrigation water depths and, the obtained data reveal that the

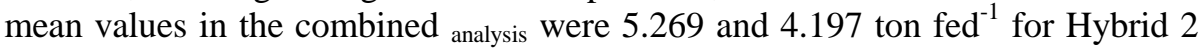
and Sakha 104, with the relative increase percentages due to applied $\mathrm{M}_{2}$ and $\mathrm{M}_{3}$ treatments of 9.78 and $13.70 \%$ over the control treatment $\left(\mathrm{M}_{1}\right)$, respectively. The corresponding mean values of grain yield were 4.517 and 4.949 ton fed ${ }^{-1}$ for $\mathrm{D}_{1}$ and $\mathrm{D}_{2}$, respectively. A similar trend was obtained for straw yield, as it is significantly increased in case of Hybrid 2 cultivar, transplanting on strips and $\mathrm{D}_{2}$ (submerged irrigation water depth at $8 \mathrm{~cm}$ ) in individual and combined seasons.

Data of over both seasons indicate that applied both $\mathrm{M}_{2}$ and $\mathrm{M}_{3}$ treatments resulted in saving water amounts reached $1890(30.15 \%)$ and $2136 \mathrm{~m}^{3} \mathrm{fed}^{-1}$ (34.06\%) as compared with $\mathrm{M}_{1}$ treatment, respectively. Data showed also that irrigation water depth was a highly effect on saving water, where the greatest value of water saved $\left(2263 \mathrm{~m}^{3} \mathrm{fed}^{-1} \approx 35.97 \%\right.$ as an average of two growing seasons) was found under irrigation water depth of $6 \mathrm{~cm}\left(\mathrm{D}_{1}\right)$. Regarding the impact of rice cultivars, Hybrid 2 recorded a greatest value of saving water (2365 $\mathrm{m}^{3} \mathrm{fed}^{-1} \approx 36.64 \%$ as an average of two growing seasons) as compared to Sakha 104 , which recorded saving water value of $2161 \mathrm{~m}^{3} \mathrm{fed} \approx 33.54 \%$ as average of two growing seasons. Thus, it is recommended by applying the transplanting of rice seedlings (Hybrid $2 \mathrm{cv}$.) on strips at $80 \mathrm{~cm}$ apart, with a submerged irrigation water depth of $8 \mathrm{~cm}$ to maximize both grain and straw yields vs saving irrigation water and increasing unit productivity of either soil or water from rice yield.

Key Words: Rice cultivars, transplanting methods, irrigation water management, irrigation water depth, growth and yield parameters of rice crop.

\section{INTRODUCTION:}

Egypt is an arid country with rapid population growth and escalating living standards. The natural and geographical conditions of Egypt are not auspicious in terms of fresh water resources availability. The generative watershed of the Nile, which is the main source of water for the country, is totally located outside Egypt's international borders. Paddy crop, i.e. rice is strongly influenced by water supply, hence water should be kept standing in the field throughout the growth period. In water scarcity areas, saturated soil in a chemical reduced stage is desirable. The characteristics of flooded soil which are conducive to high yields are: i) greater availability of nutrients such as phosphorus, iron and manganese, ii) suppression of weed competition, iii) elimination of moisture stress as a limiting factor, and iv) micro-climate favorable to crop production.

The authorities in Egypt limit the area devoted to rice to be about 1.1 million feddan every year, but the actually annual area cultivated with rice is about 1.7 million feddan ( 1 hectare $=2.5$ feddans $)$ in 2008 which produced 4.08 million tons of paddy rice with an average of 4.06 ton/fed (Statistical Database by Agric. Res. Center, Ministry of Agriculture and Land Reclamation, 2008).

In Egypt, Abdel-Hafez (1982) investigated the effect of five irrigation treatments $(5,10,15 \mathrm{~cm}$ water depth, saturation point and field capacity) on rice productivity. He found that plant height; total number of tillers per hill, panicle length, number of spikelets/panicle and percentage of ripened grains/panicle were reduced when the soil moisture content was decreased to the field capacity. He added that water requirements of rice in the Northern Delta water found to be $6900-7000 \mathrm{~m}^{3} / \mathrm{fed}$.

In spite of the great progress achieved in rice productivity still there is a need of increasing rice yield per unit area with irrigation water less. Increasing

Fayoum J. Agric. Res. \& Dev., Vol.24, No.2, July, 2010 
MAXIMIZING IRRIGATION WATER USE EFFICIENCY AND....... 3 water use efficiency of rice could be achieved by different ways, i.e., developing high yielding cultivars that having short duration such as rice cultivar of Hybrid 2 (SK 2047H) which recorded an increase in grain yield averaged $20 \%$ compared with the conventional cultivar (Sakha 104). Such increase would achieve food security in Egypt (Arafat 2007). The water resources in Egypt are considered limited although the population increasing continuously. In this sense, Egypt will not have sufficient water resources to overcome their agricultural, domestic, industrial and environmental needs. One of the main strategies to meet this problem could be achieved by using a better water management policy. Irrigation management under Egyptian land conditions of surface irrigation method is very important to improve crop productivity and saving water. For increasing water use efficiency, a special attention was focused to optimize transplanting method of rice seedlings for saving water without additional costs to the farmers.

Irrigation method is one of the applied techniques that can be implemented in rice irrigation schemes. This technique involves an effective use for reducing irrigation water through an operation of raising water use efficiency, and in turn increasing crop production. This will lead to save in costs for operation and management. So saving water is necessary to face the water shortage in the future. Such saving for irrigation water of rice will be achieved by using a new planting and irrigation methods with high potential for water saving, The present study aims to evaluate a new transplanting and irrigation methods under different irrigation water depths for two rice cultivars for maximizing water use efficiency, and consequently saving water.

\section{MATERIALS AND METHODS:}

To achieve the aforementioned target, a field experiment was conducted on a sandy clay loam soil during two successive growing summer seasons 2007 and 2008 at a private farm, Sinnuris district, Fayoum governorate, Egypt to evaluate the effect of applying a new method (M) for rice transplanting (transplanting on strips) on rice yield and its components as well as some soilwater relationships. However, rice seedlings of two rice cultivars of Hybrid 2 and Sakha 104 were transplanting at furrow bottoms of either $60 \mathrm{~cm}\left(\mathrm{M}_{2}\right)$ or $80 \mathrm{~cm}\left(\mathrm{M}_{3}\right)$ apart as compared with the traditional transplanting method $\left(\mathrm{M}_{1}\right.$, transplanting on a flat soil), under different submerged irrigation water depths of $6 \mathrm{~cm}\left(\mathrm{D}_{1}\right)$ and $8 \mathrm{~cm}\left(\mathrm{D}_{2}\right)$. Some physical and chemical properties of the studied soil and irrigation water samples were determined according to the standard methods undertaken by Gee and Bauder (1986) and Black et al. (1965), and the obtained date are presented in Table (1).

Table (1): Some properties of the studied soil and irrigation water. a. Particle size distribution

\begin{tabular}{|c|c|c|c|c|c|}
\hline \multirow{2}{*}{$\begin{array}{c}\text { Soil depth } \\
(\mathbf{c m})\end{array}$} & \multicolumn{4}{|c|}{ Particle size distribution \% } & \multirow{2}{*}{ Texture class } \\
\cline { 2 - 5 } & Coarse sand & Fine sand & Silt & Clay & \\
\hline $0-20$ & 24.5 & 36.6 & 17.4 & 21.5 & Sandy clay loam \\
\hline $20-40$ & 27.6 & 37.4 & 16.8 & 18.2 & \multirow{2}{*}{ Sandy loam } \\
\hline $40-60$ & 32.5 & 32.0 & 17.0 & 18.5 & \\
\hline
\end{tabular}

a. Chemical properties

\begin{tabular}{|c|c|c|c|c|c|c|c|c|c|c|}
\hline \multirow{2}{*}{ Sample } & \multirow{2}{*}{ pH } & \multirow{2}{*}{$\begin{array}{c}\mathrm{EC} \\
\left(\mathrm{dSm}^{-1}\right)\end{array}$} & \multicolumn{4}{|c|}{ Soluble cations $\left(\mathrm{mmolc}^{-1}\right)$} & \multicolumn{4}{|c|}{ Soluble anions $\left(\right.$ mmolc $\left.^{-1}\right)$} \\
\hline & & & $\mathrm{Ca}^{2+}$ & $\mathrm{Mg}^{2+}$ & $\mathrm{Na}^{+}$ & $\mathbf{K}^{+}$ & $\mathrm{CO}_{3}{ }^{2-}$ & $\mathrm{HCO}_{3}^{-}$ & $\mathrm{Cl}^{-}$ & $\mathrm{SO}_{4}{ }^{2-}$ \\
\hline Soil & $8.06^{*}$ & 0.79 & 2.2 & 1.8 & 3.5 & 0.6 & 0.0 & 3.2 & 2.8 & 2.1 \\
\hline Water & 7.35 & 0.58 & 1.7 & 1.0 & 2.7 & 0.4 & 0.0 & 3.0 & 1.5 & 1.3 \\
\hline
\end{tabular}

Fayoum J. Agric. Res. \& Dev., Vol.24, No.2, July, 2010 


\section{Experimental design:}

A split-split plot design with three replicates was used, field area was divided into 36 plots with an area of $150 \mathrm{~m}^{2}(12.5 \mathrm{~m}$ long $\times 12.0 \mathrm{~m}$ wide) for each one, which was isolated from the others by borders to prevent the horizontal water movement.

a. The main plots are represented by the transplanting methods $(M)$ as follow:

$\mathrm{M}_{1}$ : Traditional transplanting method, where rice seedlings were transplanting on flat soil at hills of $20 \times 20 \mathrm{~cm}$ apart to give a rate of 25 hill m .

$\mathrm{M}_{2}$ : Strip of furrows of $60 \mathrm{~cm}$ apart, where, $30 \mathrm{~cm}$ was for either furrow top (border) or bottom (tape), and the seedlings were transplanting in hills of $13 \mathrm{~cm}$ apart in the two rows on the bottoms of furrow (tapes), keeping population as the same recommended in the traditional method ( 25 hills $\mathrm{m}^{-2}$ ), as shown in Fig. (1).

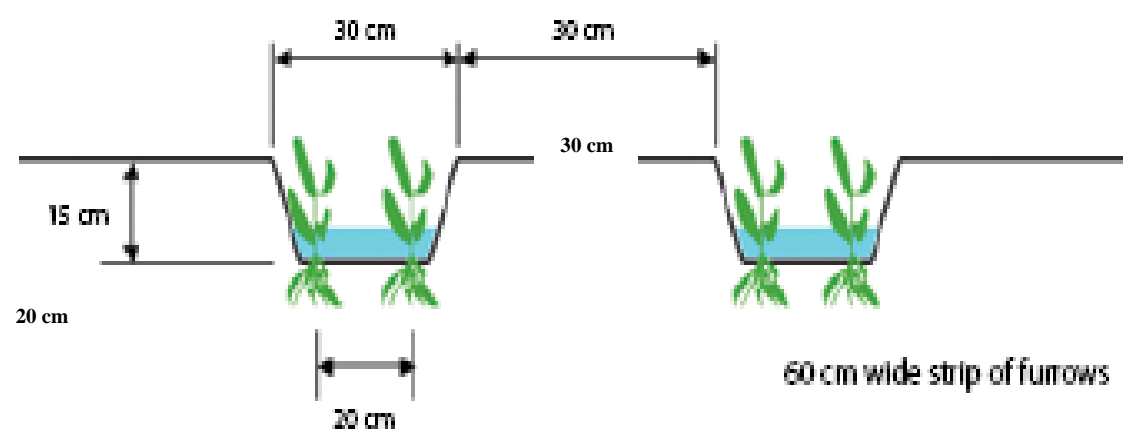

Fig. (1). Cross-sectional strips of furrows diagram $(60 \mathrm{~cm}$ wide)

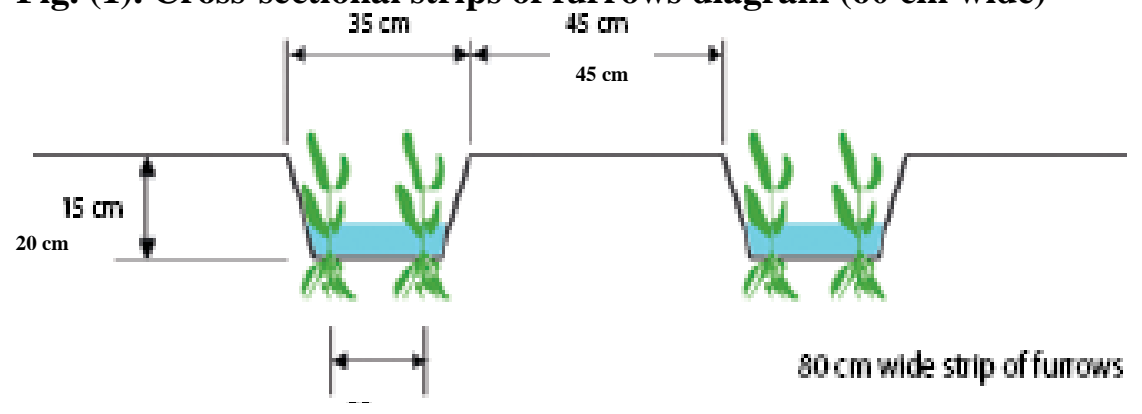

Fig. (2). Cross-sectiơngal strips of furrows diagram $(80 \mathrm{~cm}$ wide).

$\mathrm{M}_{3}$ : Strip of furrows of $80 \mathrm{~cm}$ apart, where, $30 \mathrm{~cm}$ was for either furrow top (border) or bottom (tape), and the seedlings were transplanting in hills of $13 \mathrm{~cm}$ apart in the two rows on the bottoms of furrow (tapes), keeping population as the same recommended in the traditional method (25hills $\mathrm{m}^{-2}$ ), as shown in Fig. (2).

b. The sub-main plots are the rice cultivars $(C)$ as follow:

$\mathrm{C}_{1}$ : (SK $\left.2047 \mathrm{H}\right)$ Hybrid 2.

$\mathrm{C}_{2}$ : Sakha 104.

Fayoum J. Agric. Res. \& Dev., Vol.24, No.2, July, 2010 
$C$ - The treatments:

$\mathrm{D}_{1}: 6 \mathrm{~cm}$ of irrigation water depth.

$\mathrm{D}_{2}: 8 \mathrm{~cm}$ of irrigation water depth.

\section{Meteorological data:}

The investigated area was about $6500 \mathrm{~m}^{2}$, and some meteorological data of the location, which lies between $30^{\circ} 50^{\prime} \mathrm{N}$ latitude and $30^{\circ} 42^{\prime} \mathrm{E}$ longitude, for the two growing seasons are presented in Table (2).

Table (2): Monthly maximum and minimum temperature $\left(\mathrm{C}^{\circ}\right)$, relative humidity $(\%)$ and evaporation (Epan) at Atsa meteorological station, Fayoum governorate in 2007 and 2008 seasons.

\begin{tabular}{|c|c|c|c|c|c|}
\hline Month of & \multicolumn{7}{|c|}{ Temperature $\left(\mathbf{C}^{\mathbf{0}}\right)$} & \multicolumn{2}{c|}{ Relative humidity (\%) } & Evaporation \\
\hline growth & Maximum & Minimum & Maximum & Minimum & (mm/day) \\
\hline \multicolumn{7}{|c|}{ First season (2007) } \\
\hline May & 35.2 & 17.7 & 75.0 & 20.0 & 6.7 \\
\hline June & 39.3 & 20.7 & 78.3 & 22.0 & 8.0 \\
\hline July & 38.9 & 21.8 & 79.8 & 20.0 & 7.2 \\
\hline August & 37.8 & 21.7 & 79.0 & 25.0 & 6.5 \\
\hline September & 34.3 & 20.5 & 77.7 & 30.0 & 5.5 \\
\hline October & 32.1 & 18.3 & 79.8 & 30.0 & 3.9 \\
\hline \multicolumn{7}{|c|}{ Second season (2008) } \\
\hline May & 35.6 & 18.0 & 74.7 & 19.0 & 7.0 \\
\hline June & 39.4 & 22.0 & 79.0 & 20.0 & 7.8 \\
\hline July & 37.7 & 22.1 & 79.3 & 22.0 & 6.9 \\
\hline August & 38.6 & 22.2 & 78.7 & 27.0 & 6.0 \\
\hline September & 35.9 & 20.0 & 77.6 & 21.0 & 5.6 \\
\hline October & 31.5 & 17.2 & 78.1 & 26.0 & 4.9 \\
\hline
\end{tabular}

3. Nursery and seed rate per fed:

The nursery seedlings preparation was well performed and fertilized with calcium super phosphate $\left(15.5 \% \mathrm{P}_{2} \mathrm{O}_{5}\right)$ at the rate of $100 \mathrm{~kg} / \mathrm{fed}$ before the first tillage. Nitrogen was added in the form of urea $(46 \% \mathrm{~N})$ at the rate of 60 $\mathrm{kg} /$ fed after the last harrowing and before land leveling, zinc sulphate at the rate of $10 \mathrm{~kg} / \mathrm{fed}$ was added after paddling. Seed rates of $10 \mathrm{~kg} / \mathrm{fed}$ as recommended for the Hybrid 2 (SK $2047 \mathrm{H}$ ) and $60 \mathrm{~kg} / \mathrm{fed}$ for the conventional rice cultivar of Sakha104. Seeds were soaked in the running water for 24 hours and incubated for 48 hours there after, they were manually broadcasted. All other cultural practice for rice production were followed, cultivars were sown in separate nursery beds in the two growing seasons of 2007 and 2008. The transplanting was carried out after 30 days from seedling, i.e., planting nurseries on 15 May, transplanting on 15 June and harvesting for the studied two growing seasons on 5 October.

\section{Water relations:}

In the two growing seasons of the current experiment and irrigation water at both the studied depths were measured by using a cut throat flume of $(20 \times 90 \mathrm{~cm})$ according to Walker and Skogerbae (1987). Total water used $\left(\mathrm{m}^{3} / \mathrm{fed}\right)$, water saving $(\%)$, and grain yield per water unit $\left(\mathrm{kg} / \mathrm{m}^{3}\right)$ were also measured.

Fayoum J. Agric. Res. \& Dev., Vol.24, No.2, July, 2010 


\section{Sampling and studied traits:}

Yield was determined at the end of the experiment from the central rows and furrows with $42 \mathrm{~m}^{2}$ for each plot. The outer rows or furrows of the plot sides were left as borders. Random plant samples were taken of each experimental unit to estimate the following characters:

a. Growth characters, i.e., plant height.

b. Yield and its component, i.e., panicle length, 1000-grain weight, grain and straw yields.

\section{Statistical analysis:}

The obtained results were statistically analyzed by using a technique of variance analysis (ANOVA) according to Snedecor and Cochran (1980) and the treatments were compared using L.S.D. at 0.05 level of probability.

\section{RESULTS AND DISCUSSION:}

\section{Effect of transplanting methods (M) and water depths $(D)$ :}

\section{a. Plant height:}

The data of plant height as affected by transplanting methods and irrigation water depths of two rice cultivars in the individual or combined seasons are shown in Table (4). The data indicate that highly significant differences existed among the planting methods, where the mean values in combined analysis for the plant heights were 100.30, 105.18 and $107.12 \mathrm{~cm}$ for $\mathrm{M}_{1}, \mathrm{M}_{2}$ and $\mathrm{M}_{3}$ treatments, respectively. The reduction in plant height could be attributed to reduction in cell turgid that causes reduction in cell enlargement, which in turn decreases shoots enlargement.

Regarding irrigation water depths, it was clear that increasing water depth from 6 to $8 \mathrm{~cm}$, significantly increased plant height in the individual or combined seasons. The tallest plants were found when rice plants were irrigated with a water depth of $8 \mathrm{~cm}$. The results are in harmony with those obtained by El-Wehishy and Abdel Hafez (1998) and Zayed et al. (2007).

As for rice cultivars, data in Table (3) indicated that plants of Hybrid 2 (Sk 2047 H) were significantly taller than Sakha 104 cultivar in the individual or combined seasons. The corresponding values of plant heights were 107.1 and $101.3 \mathrm{~cm}$ as averages of the two growing seasons, respectively. The superiority of Hybrid 2 cultivar may due to it is more vigorous in crop growth, more responsive to fertilizers and more adaptable to different crop environments as compared with conventional cultivar of Sakha 104 (Arafat, 2007). Also, El-Hawary (2000), El-Khoby (2004) and Zayed et al. (2007) emphasized such differences to the genotypic variation exists between the two studied rice cultivars.

\section{b. Panicle length:}

Data in Table (4) showed the effect of planting methods and irrigation water depths of two rice cultivars on panicle length $(\mathrm{cm})$ was significantly increased in cases of $\mathrm{M}_{2}$ and $\mathrm{M}_{3}$ treatments as compared to the traditional transplanting methods $M_{1}$ as shown in both individual and combined seasons. 
MAXIMIZING IRRIGATION WATER USE EFFICIENCY AND.......

Table (3): Plant height $(\mathrm{cm})$ as affected by planting methods and water depths for the two rice cultivars in two growing seasons $(2007 \& 2008)$

\begin{tabular}{|c|c|c|c|}
\hline Treatments & $\begin{array}{c}1^{\text {st }} \text { season } \\
2007\end{array}$ & $\begin{array}{c}2^{2^{n d}} \text { season } \\
2008\end{array}$ & Combined \\
\hline \multicolumn{4}{|c|}{ Planting methods $(M):$} \\
\hline M1: Traditional method. & $100.96 \mathrm{c}$ & $99.64 \mathrm{c}$ & $100.30 \mathrm{c}$ \\
\hline M2: Strips of furrows $(60 \mathrm{~cm})$. & $105.34 \mathrm{~b}$ & $105.02 \mathrm{~b}$ & $105.18 \mathrm{~b}$ \\
\hline M3: Strips of furrows $(80 \mathrm{~cm})$. & $107.38 \mathrm{a}$ & $106.86 \mathrm{a}$ & $107.12 \mathrm{a}$ \\
\hline F-test & $* *$ & $* *$ & $* *$ \\
\hline \multicolumn{4}{|c|}{ Water depths $(D):$} \\
\hline D1: $6 \mathrm{~cm}$. & $102.12 \mathrm{~b}$ & $101.84 \mathrm{~b}$ & $101.98 \mathrm{~b}$ \\
\hline $\mathrm{D} 2: 8 \mathrm{~cm}$. & $107.00 \mathrm{a}$ & $101.84 \mathrm{~b}$ & $101.98 \mathrm{~b}$ \\
\hline F-test & $* *$ & $* *$ & $* *$ \\
\hline \multicolumn{4}{|c|}{ Cultivars $(C)$ : } \\
\hline C1: Hybrid 2 & $107.77 \mathrm{a}$ & $106.43 \mathrm{a}$ & $107.10 \mathrm{a}$ \\
\hline C2: Sakha104 & $101.35 \mathrm{~b}$ & $101.25 \mathrm{~b}$ & $101.30 \mathrm{~b}$ \\
\hline F-test & $* *$ & $* *$ & $* *$ \\
\hline \multicolumn{4}{|c|}{ Interactions: } \\
\hline $\mathrm{M} \times \mathrm{D}$ & N.S. & N.S. & N.S. \\
\hline $\mathrm{M} \times \mathrm{C}$ & N.S. & N.S. & $*$ \\
\hline $\mathrm{D} \times \mathrm{C}$ & $*$ & $* *$ & $*$ \\
\hline $\mathrm{M} \times \mathrm{D} \times \mathrm{C}$ & N.S. & N.S. & N.S. \\
\hline
\end{tabular}

*, ** and N.S. medicate $\mathrm{P}<0.05, \mathrm{P}<0.01$ and not significant, respectively. Means designated by the same letter are insignificant differences at the $5 \%$ level according to LSD-Test.

This could be attributed to good utilization of light, where plants were arranged in two rows at furrow bottoms of 60 or $80 \mathrm{~cm}$ apart. Results indicate also that the greatest values of panicle length were recorded for $\mathrm{M}_{3}$ treatment followed by $\mathrm{M}_{2}$ one, with an insignificant difference in both individual and combined seasons. In general, the mean values of the panicle length in combined analysis were $19.56,20.93$ and $21.70 \mathrm{~cm}$ for $\mathrm{M}_{1}, \mathrm{M}_{2}$ and $\mathrm{M}_{3}$ treatments, respectively. These results are in harmony with the obtained data of irrigation water depths, as it was clear that increasing water depth from 6 $\mathrm{cm}\left(\mathrm{D}_{1}\right)$ to $8 \mathrm{~cm}\left(\mathrm{D}_{2}\right)$ led to a significantly increased in panicle length, where the corresponding value in the combined analysis were 19.98 and $21.48 \mathrm{~cm}$, respectively. These findings are in agreement with those obtained by Biswas and Bhattacharyya (1987) and El-Hadidi (2002).

Data indicated that the rice cultivars significantly varied in their panicle length in both individual and combined seasons (Table 4), where Hybrid 2 gave the tallest panicles as compared with Sakha 104 cultivar. The superiority of Hybrid 2 could be attributed to its genetic constitution. Similar results were obtained by Abdel-Hameed (2002) and Zayed $\boldsymbol{e t}$ al. (2007). The interactions between the studied factors have insignificant effects on panicle length either in either individual or combined seasons. 
Table (4): Panicle length (cm) as affected by planting methods and water depths of two rice cultivars in two growing seasons $(2007 \& 2008)$.

\begin{tabular}{|c|c|c|c|}
\hline Treatments & $\begin{array}{c}1^{\text {st }} \text { season } \\
2007\end{array}$ & $\begin{array}{c}2^{\frac{\text { nd }}{2}} \text { season } \\
2008\end{array}$ & Combined \\
\hline \multicolumn{4}{|c|}{ Planting methods $(M):$} \\
\hline M1: Traditional method. & $19.72 \mathrm{~b}$ & $19.40 \mathrm{~b}$ & $19.56 \mathrm{~b}$ \\
\hline M2: Strips of furrows $(60 \mathrm{~cm})$. & $21.05 \mathrm{a}$ & $20.81 \mathrm{a}$ & $20.93 \mathrm{a}$ \\
\hline M3: Strips of furrows $(80 \mathrm{~cm})$. & $22.02 \mathrm{a}$ & $21.38 \mathrm{a}$ & $21.70 \mathrm{a}$ \\
\hline F-test & $*$ & & \\
\hline \multicolumn{4}{|c|}{ Water depths $(D)$ : } \\
\hline $\mathrm{D} 1: 6 \mathrm{~cm}$ & $20.24 \mathrm{~b}$ & $19.72 \mathrm{~b}$ & $19.98 \mathrm{~b}$ \\
\hline $\mathrm{D} 2: 8 \mathrm{~cm}$. & $21.62 \mathrm{a}$ & $21.34 \mathrm{a}$ & $21.48 \mathrm{a}$ \\
\hline F-test & $*$ & $* *$ & $* *$ \\
\hline \multicolumn{4}{|c|}{ Cultivars (C): } \\
\hline C1: Hybrid 2 & $22.12 \mathrm{a}$ & $21.82 \mathrm{a}$ & $21.97 \mathrm{a}$ \\
\hline C2: Sakha104 & $19.74 \mathrm{~b}$ & $19.24 \mathrm{~b}$ & $19.49 \mathrm{~b}$ \\
\hline F-test & $* *$ & $* *$ & $* *$ \\
\hline \multicolumn{4}{|c|}{ Interactions: } \\
\hline$M \times D$ & N.S. & N.S. & N.S. \\
\hline $\mathrm{M} \times \mathrm{C}$ & N.S. & N.S. & N.S. \\
\hline $\mathrm{D} \times \mathrm{C}$ & N.S. & N.S. & N.S. \\
\hline $\mathrm{M} \times \mathrm{D} \times \mathrm{C}$ & N.S. & N.S. & N.S. \\
\hline
\end{tabular}

*, ** and N.S. medicate $\mathrm{P}<0.05, \mathrm{P}<0.01$ and not significant, respectively. Means designated

by the same letter are insignificant differences at the $5 \%$ level according to LSD-Test.

\section{c. Weight of 1000 grain:}

Weight of 1000-grain as affected by planting methods, irrigation water depths and two rice cultivars in both individual and combined seasons is presented in Table (5). The averages of 1000 grain weight of rice were 26.13, 28.71 and 29.25 gm for $\mathrm{M}_{1}, \mathrm{M}_{2}$ and $\mathrm{M}_{3}$ treatments, respectively. This could be attributed to good utilization of light and, where plants were arranged two rows at furrow bottoms which increasing fertilizers use efficiency (Atta, 2005).

Concerning irrigation water depths, it is clear that increasing water depths from 6 to $8 \mathrm{~cm}$, significantly increased 1000 grain weight in both individual and combined seasons, with superiority for $\mathrm{D}_{2}$ treatment that gave the greatest value for this trait $(29.53 \mathrm{gm})$ as compared with $\mathrm{D}_{1}(26.53 \mathrm{gm})$. However, decreasing water depth caused a depression in dry matter content of rice plants, and hence smaller grains were produced owing to relative less water and dry matter production (El-Refaee, 2002). According to data in Table (5), Sakha 104 cultivar exceeded significantly Hybrid 2 for this trait, where the mean values were 28.97 and $26.53 \mathrm{gm}$, respectively. Such differences could be attributed to genetic effect. Similar results were obtained by Arafat (2007) and Mohammed (2006). The interaction between transplanting methods, irrigation water depths and cultivars showed insignificant effect on 1000 grain weight in both seasons and their combined. 
MAXIMIZING IRRIGATION WATER USE EFFICIENCY AND.......

Table (5): 1000-grains weight (gm) as affected by planting methods and water depths of two rice cultivars in two growing seasons ( $2007 \& 2008)$.

\begin{tabular}{|c|c|c|c|}
\hline Treatments & $\begin{array}{c}1^{1^{\text {st }}} \text { season } \\
2007\end{array}$ & $\begin{array}{c}2^{2^{\text {nd }}} \text { season } \\
2008\end{array}$ & Combined \\
\hline \multicolumn{4}{|c|}{ Planting methods $(M):$} \\
\hline M1: Traditional method. & $25.88 \mathrm{~b}$ & $26.38 \mathrm{~b}$ & $26.13 \mathrm{~b}$ \\
\hline M2: Strips of furrows $(60 \mathrm{~cm})$ & $28.21 \mathrm{a}$ & $29.21 \mathrm{a}$ & $28.71 \mathrm{a}$ \\
\hline M3: Strips of furrows $(80 \mathrm{~cm})$. & $28.74 \mathrm{a}$ & $29.76 \mathrm{a}$ & $29.25 \mathrm{a}$ \\
\hline F-test & $* *$ & $* *$ & $* *$ \\
\hline \multicolumn{4}{|c|}{ Water depths $(D)$ : } \\
\hline D1: $6 \mathrm{~cm}$ & $25.90 \mathrm{~b}$ & $27.16 \mathrm{~b}$ & $26.53 \mathrm{~b}$ \\
\hline D2: $8 \mathrm{~cm}$. & $29.32 \mathrm{a}$ & $29.74 \mathrm{a}$ & $29.53 \mathrm{a}$ \\
\hline F-test & ** & $* *$ & $* *$ \\
\hline \multicolumn{4}{|c|}{ Cultivars $(C)$ : } \\
\hline C1: Hybrid 2 & $26.60 \mathrm{~b}$ & $27.58 \mathrm{~b}$ & $26.53 \mathrm{~b}$ \\
\hline C2: Sakha104 & $28.62 \mathrm{a}$ & $29.74 \mathrm{a}$ & $28.97 \mathrm{a}$ \\
\hline F-test & $* *$ & $* *$ & $* *$ \\
\hline \multicolumn{4}{|c|}{ Interactions: } \\
\hline$M \times D$ & N.S. & N.S. & N.S. \\
\hline $\mathrm{MxC}$ & N.S. & N.S. & N.S. \\
\hline $\mathrm{D} \times \mathrm{C}$ & N.S. & N.S. & N.S. \\
\hline$M \times D \times C$ & N.S. & N.S. & N.S. \\
\hline
\end{tabular}

$*$, ** and N.S. medicate $\mathrm{P}<0.05, \mathrm{P}<0.01$ and not significant, respectively. Means designated by the same letter are insignificant different at the $5 \%$ level according to LSD-Test.

\section{d. Grain yield:}

Effect of transplanting methods and irrigation water depths as well as their interactions on grain yield of the two rice cultivars in both individual seasons and their combined is presented in Table (6). The obtained data indicated that $\mathrm{M}_{3}$ treatment produced the greatest grain yield (5.011 ton/ fed), followed by $\mathrm{M}_{2}$ (4.795 ton/ fed), with insignificant differences between them. Grain yield was exhibited pronounced increases for treatments of $\mathrm{M}_{2}$ and $\mathrm{M}_{3}$, where the corresponding relative increase percentages were 9.78 and $13.70 \%$ over the control treatment of $\mathrm{M}_{1}$, respectively. These increases in grain yield for treatments of $M_{2}$ and $M_{3}$ may be attributed to the increase in the dry matter production, number of panicles $\mathrm{m}^{-2}$, number of filled grains/ panicle, panicle grain weight and 1000 grain weight. These results are in agreement with those obtained by Atta (2005).

With respect to the impact of irrigation water depths, the data also revealed that, increasing water depths from 6 to $8 \mathrm{~cm}$ resulted in significantly increased for grain yield in both seasons and their combined analysis. However, grain yield values in combined analysis were 4.517 and 4.949 ton/fed for $D_{1}$ and $D_{2}$ treatments, respectively. These findings are in agreement with those obtained by El-Kholy (2004). 
Table (6): Grain yield (ton/fed) as affected by planting methods and water depths of two rice cultivars in two growing seasons $(2007 \& 2008)$.

\begin{tabular}{|c|c|c|c|}
\hline Treatments & $\begin{array}{c}1^{\text {st }} \text { season } \\
2007\end{array}$ & $\begin{array}{c}2^{\frac{\mathrm{nd}}{4}} \text { season } \\
2008\end{array}$ & Combined \\
\hline \multicolumn{4}{|c|}{ Planting methods $(M)$ : } \\
\hline M1: Traditional method. & $4.405 \mathrm{~b}$ & $4.381 \mathrm{~b}$ & $4.393 \mathrm{~b}$ \\
\hline M2: Strips of furrows $(60 \mathrm{~cm})$ & $4.835 \mathrm{a}$ & $4.755 \mathrm{a}$ & $4.795 \mathrm{a}$ \\
\hline M3: Strips of furrows $(80 \mathrm{~cm})$ & $5.058 \mathrm{a}$ & $4.964 \mathrm{a}$ & $5.011 \mathrm{a}$ \\
\hline F-test & $* *$ & $* *$ & $* *$ \\
\hline \multicolumn{4}{|c|}{ Water depths $(D)$ : } \\
\hline D1: $6 \mathrm{~cm}$ & $\overline{4.550 \mathrm{~b}}$ & $4.484 \mathrm{~b}$ & $4.517 \mathrm{~b}$ \\
\hline D2: $8 \mathrm{~cm}$. & $4.982 \mathrm{a}$ & $4.916 \mathrm{a}$ & $4.949 \mathrm{a}$ \\
\hline F-test & $* *$ & $* *$ & $* *$ \\
\hline \multicolumn{4}{|c|}{ Cultivars (C): } \\
\hline C1: Hybrid 2 & $\overline{5.272} \mathrm{a}$ & $5.266 \mathrm{a}$ & $5.269 \mathrm{a}$ \\
\hline C2: Sakha104 & $4.260 \mathrm{~b}$ & $4.134 \mathrm{~b}$ & $4.197 \mathrm{~b}$ \\
\hline F-test & $* *$ & $* *$ & $* *$ \\
\hline \multicolumn{4}{|c|}{ Interactions: } \\
\hline$M \times D$ & $\overline{N . S .}$ & N.S. & N.S. \\
\hline $\mathrm{MxC}$ & N.S. & N.S. & N.S. \\
\hline $\mathrm{D} \times \mathrm{C}$ & N.S. & N.S. & $*$ \\
\hline$M \times D \times C$ & N.S. & N.S. & N.S. \\
\hline
\end{tabular}

$*, * *$ and N.S. medicate $\mathrm{P}<0.05, \mathrm{P}<0.01$ and not significant, respectively. Means designated

by the same letter are insignificant different at the $5 \%$ level according to LSD-Test.

The analysis of variance in Table (6) showed that the differences were significant between the two rice cultivars for grain yield in both seasons and their combined. In this respect, Hybrid 2 cultivar recorded the greatest grain yield with a significant difference than Sakha 104 cultivar. The corresponding mean values were 5.269 and 4.197 ton/fed in combined analysis, respectively. Such differences could be attributed to yield components, i.e., number of panicles $/ \mathrm{m}^{2}$, number of filled grains, panicle grain weight as well as genetic effect. These findings are in agreement with those reported by El-Kholy (2004) and Zayed et al. (2007). Concerning the interaction, there are insignificant differences, except for the interaction between rice cultivars and irrigation water depths (D x C) which had a significant effect on grain yield in the combined only (Table 6).

\section{e. Straw yield:}

Effect of transplanting methods and irrigation water depths as well their interactions on straw yield of the two rice cultivars in both seasons and their combined is presented in Table (7). The obtained data indicated that straw yield was significantly influenced by transplanting methods in both seasons their and combined. $\mathrm{M}_{3}$ treatment produced the greatest straw yield (6.550 ton/fed), followed by $\mathrm{M}_{2}$ treatment (6.220 ton/fed), with insignificant difference between them. These results could mainly attributed to the improvement of vegetative growth for treatment $\mathbf{M}_{3}$ and $\mathbf{M}_{2}$ due to increasing plant height, number of tillers and dry matter production.

Regarding the effect of irrigation water depths, data in Table (7), indicated also that a highly significant effect on rice straw yield in

Fayoum J. Agric. Res. \& Dev., Vol.24, No.2, July, 2010 
both growing seasons and their combined. This beneficial effect is more attributed to the pronounced increases in plant height and number of tillers $/ \mathrm{m}^{2}$. A similar trend was obtained by Biswas and Bahattacharye (1987), ElHadidi et al. (2002) and Zayed et al. (2007).

Table (7): Straw yield (ton/fed) as affected by planting methods and water depths of two rice cultivars in two growing seasons $(2007 \& 2008)$.

\begin{tabular}{|c|c|c|c|}
\hline Treatments & $\begin{array}{c}1^{\text {st }} \text { season } \\
2007\end{array}$ & $\begin{array}{c}2^{\text {nd }} \text { season } \\
2008\end{array}$ & Combined \\
\hline \multicolumn{4}{|c|}{ Planting methods $(M):$} \\
\hline M1: Traditional method. & $5.855 \mathrm{c}$ & $5.907 \mathrm{~b}$ & $5.858 \mathrm{~b}$ \\
\hline M2: Strips of furrows $(60 \mathrm{~cm})$. & $6.305 \mathrm{~b}$ & $6.135 \mathrm{~b}$ & $6.220 \mathrm{a}$ \\
\hline M3: Strips of furrows $(80 \mathrm{~cm})$. & $6.590 \mathrm{a}$ & $6.522 \mathrm{a}$ & $6.550 \mathrm{a}$ \\
\hline F-test & $* *$ & $* *$ & $* *$ \\
\hline \multicolumn{4}{|c|}{ Water depths $(D):$} \\
\hline D1: $6 \mathrm{~cm}$ & $6.080 \mathrm{~b}$ & $5.996 \mathrm{~b}$ & $6.380 \mathrm{~b}$ \\
\hline D2: $8 \mathrm{~cm}$ & $6.438 \mathrm{a}$ & $6.449 \mathrm{a}$ & $6.443 \mathrm{a}$ \\
\hline F-test & $*$ & $* *$ & $* *$ \\
\hline \multicolumn{4}{|c|}{ Cultivars $(C)$ : } \\
\hline C1: Hybrid 2 & $\overline{6.888} \mathrm{a}$ & $6.964 \mathrm{a}$ & $6.926 \mathrm{a}$ \\
\hline C2: Sakha104 & $5.612 \mathrm{~b}$ & $5.412 \mathrm{~b}$ & $5.512 \mathrm{~b}$ \\
\hline F-test & $* *$ & $* *$ & $* *$ \\
\hline \multicolumn{4}{|c|}{ Interactions: } \\
\hline$M \times D$ & N.S. & N.S. & N.S. \\
\hline $\mathrm{M} \times \mathrm{C}$ & N.S. & N.S. & N.S. \\
\hline $\mathrm{D} \times \mathrm{C}$ & N.S. & $* *$ & N.S. \\
\hline $\mathrm{M} \times \mathrm{D} \times \mathrm{C}$ & N.S. & N.S. & N.S. \\
\hline
\end{tabular}

$*$, ** and N.S. medicate $\mathrm{P}<0.05, \mathrm{P}<0.01$ and not significant, respectively. Means designated by the same letter are insignificant different at the $5 \%$ level according to LSD-Test.

Data in Table (7) showed that there was a significant difference between the effect of two rice cultivars on straw yield/fed in both seasons and their combined. The mean values were 6.926 and 5.512 ton/fed for Hybride 2 and Sakha 104 cultivars, respectively. The superiority of Hybride 2 cultivar in straw yield may be due to the increase in number of tillers $/ \mathrm{m}^{2}$, dry matter production as well as genetic effect. These results are satisfactorily consistent with those of Arfat (2007), El-Kholy (2004), Mohammed (2006) and Zayed et al. (2007).

\section{f. Saving water:}

Data presented in Tables ( 8 and 9) showed that the amount of water saved $\left(\mathrm{m}^{3} /\right.$ fed or percent) are $\mathrm{s}$ significantly affected by the applied transplanting methods and water depths of the two rice cultivars during the two studied seasons and overall average. Data of over both seasons indicate that applied both $\mathrm{M}_{2}$ and $\mathrm{M}_{3}$ treatments resulted in saving water amounts reached $1890(30.15 \%)$ and $2136 \mathrm{~m}^{3} \mathrm{fed}^{-1}(34.06 \%)$ as compared with $\mathrm{M}_{1}$ treatment, respectively. This could be attributed to irrigation water was added to furrow bottoms (tapes), which were less in the treatment of $\mathrm{M}_{3}$ than those in

Fayoum J. Agric. Res. \& Dev., Vol.24, No.2, July, 2010 
$\mathrm{M}_{2}$ treatment, and consequently saving water for $\mathrm{M}_{3}$ was more higher than $\mathrm{M}_{2}$.

These findings are in accordance with that reported by Atta (2005).

Table (8): Water saved $\left(\mathrm{m}^{3} / \mathrm{fed}\right)$ as affected by planting methods and water depths of two rice cultivars in 2007 and 2008 seasons and overall average.

\begin{tabular}{|c|c|c|c|c|c|c|c|c|}
\hline \multicolumn{2}{|c|}{ Treatments } & \multicolumn{2}{|c|}{2007} & \multicolumn{2}{|c|}{2008} & \multicolumn{2}{|c|}{ Average } & \multirow{2}{*}{$\begin{array}{l}\text { Overall } \\
\text { average }\end{array}$} \\
\hline $\begin{array}{c}\text { Planting } \\
\text { methods }(M)\end{array}$ & $\begin{array}{l}\text { Irrigation } \\
\text { depths (D) }\end{array}$ & $\begin{array}{c}\text { Sakha } \\
104\end{array}$ & Hybrid 2 & $\begin{array}{c}\text { Sakha } \\
104\end{array}$ & Hybrid 2 & $\begin{array}{c}\text { Sakha } \\
104\end{array}$ & Hybrid 2 & \\
\hline \multirow{3}{*}{$\mathbf{M}_{2}$} & $\mathrm{D}_{1}$ & 2015 & 2104 & 1843 & 2178 & 1929 & 2141 & 2035.5 \\
\hline & $\mathrm{D}_{2}$ & 1862 & 1964 & 1840 & 2082 & 1851 & 2023 & 1937.0 \\
\hline & Mean & 1938.5 & 2034 & 1841.5 & 2130 & 1890 & 2082 & 1986.0 \\
\hline \multirow{3}{*}{$\mathbf{M}_{3}$} & $\mathrm{D}_{1}$ & 2168 & 2344 & 2154 & 2386 & 2161 & 2365 & 2263.0 \\
\hline & $\mathrm{D}_{2}$ & 2125 & 2263 & 2097 & 2359 & 2111 & 2311 & 2111.0 \\
\hline & Mean & 2146.5 & 2303.5 & 2125.5 & 2372.5 & 2136 & 2338 & 2237.0 \\
\hline
\end{tabular}

Table (9) Water saved (\%) as affected by planting methods and water depths of two rice cultivars in 2007and 2008 seasons and overall average.

\begin{tabular}{|c|c|c|c|c|c|c|c|c|}
\hline \multicolumn{2}{|c|}{ Treatments } & \multicolumn{2}{|c|}{2007} & \multicolumn{2}{|c|}{2008} & \multicolumn{2}{|c|}{ Averages } & \multirow[b]{2}{*}{$\begin{array}{l}\text { Overall } \\
\text { average }\end{array}$} \\
\hline $\begin{array}{c}\text { Planting } \\
\text { methods (M) }\end{array}$ & $\begin{array}{l}\text { Irrigation } \\
\text { depths (D) }\end{array}$ & $\begin{array}{c}\text { Sakha } \\
104\end{array}$ & Hybrid 2 & $\begin{array}{c}\text { Sakha } \\
104\end{array}$ & Hybrid 2 & $\begin{array}{c}\text { Sakha } \\
104\end{array}$ & Hybrid 2 & \\
\hline \multirow{3}{*}{$M_{2}$} & $\mathrm{D}_{1}$ & 32.95 & 32.88 & 30.08 & 33.45 & 31.51 & 33.17 & 32.34 \\
\hline & $\mathrm{D}_{2}$ & 29.15 & 29.90 & 28.42 & 30.86 & 28.78 & 30.38 & 29.58 \\
\hline & Mean & 31.05 & 31.39 & 29.25 & 32.16 & 30.15 & 31.77 & 30.96 \\
\hline \multirow{3}{*}{$\mathbf{M}_{3}$} & $\mathrm{D}_{1}$ & 35.45 & 36.64 & 35.16 & 36.64 & 35.30 & 36.64 & 35.97 \\
\hline & $\mathrm{D}_{2}$ & 33.27 & 34.45 & 32.39 & 34.96 & 32.83 & 34.71 & 33.77 \\
\hline & Mean & 34.36 & 35.54 & 33.78 & 35.80 & 34.06 & 35.67 & 34.87 \\
\hline
\end{tabular}

Also, the obtained data indicated that irrigation water depth was a highly affect saving water, where the greatest value the greatest value of water saved $\left(2263 \mathrm{~m}^{3} \mathrm{fed}^{-1} \approx 35.97 \%\right.$ as an average of two growing seasons) was found under irrigation water depth of $6 \mathrm{~cm}\left(\mathrm{D}_{1}\right)$. Regarding the impact of rice cultivars, Hybrid 2 recorded a greatest value of saving water $\left(2365 \mathrm{~m}^{3} \mathrm{fed}^{-1} \approx\right.$ $36.64 \%$ as an average of two growing seasons) as compared to Sakha 104, which recorded saving water value of $2161 \mathrm{~m}^{3} \mathrm{fed} \approx 33.54 \%$ as average of two growing seasons. Such differences could be attributed to decreasing nursery area of Hybrid 2, and consequently less water added before treatments although Hybrid2 was long duration (140 days) than Sakha 104 cultivar (135 days). Thus, it is recommended by applying the transplanting of rice seedlings (Hybrid $2 \mathrm{cv}$.) on strips at $80 \mathrm{~cm}$ apart, with a submerged irrigation water depth of $8 \mathrm{~cm}$ to maximize both grain and straw yields vs saving irrigation water and increasing unit productivity of either soil or water from rice yield.

\section{g. Grain yield productivity per water unit:}

Grain yield productivity per water unit $\left(\mathrm{kg} / \mathrm{m}^{3}\right)$ as affected by transplanting methods and irrigation water depths for the two rice cultivars in both studied seasons and their means are shown in Table (10). Over both two seasons, the obtained data showed that the values of grain yield per water unit were $0.67,1.04$ and $1.14 \mathrm{~kg} / \mathrm{m}^{3}$ for $\mathrm{M}_{1}, \mathrm{M}_{2}$ and $\mathrm{M}_{3}$ treatments, respectively. It is noteworthy to mention that although $\mathrm{M}_{3}$ treatment was received a relatively

Fayoum J. Agric. Res. \& Dev., Vol.24, No.2, July, 2010 
less amount of irrigation water than other treatments, yet it gave the greatest value of grain yield per water unit. Also, data in Table (10) showed that irrigation water depth was a highly effect on grain yield productivity per water unit during the two growing seasons, with a greatest value $\left(0.97 \mathrm{~kg} / \mathrm{m}^{3}\right)$ was found under irrigation water depth of $8 \mathrm{~cm}\left(\mathrm{D}_{2}\right)$ as compared to $\mathrm{D}_{1}(0.93 \mathrm{~kg} /$ $\left.\mathrm{m}^{3}\right)$.

Table (10): Yield productivity per water unit as affected by transplanting methods and water depths for the two rice cultivars in 2007 and 2008 seasons.

\begin{tabular}{|c|c|c|c|c|c|c|c|c|}
\hline \multicolumn{2}{|c|}{ Treatments } & \multicolumn{2}{|c|}{2007} & \multicolumn{2}{|c|}{2008} & \multicolumn{2}{|c|}{ Average } & \multirow[b]{2}{*}{$\begin{array}{c}\text { Overall } \\
\text { average }\end{array}$} \\
\hline $\begin{array}{c}\text { Planting } \\
\text { methods }(\mathrm{M})\end{array}$ & $\begin{array}{l}\text { Irrigation } \\
\text { depths (D) }\end{array}$ & $\begin{array}{c}\text { Sakha } \\
104 \\
\end{array}$ & Hybrid 2 & $\begin{array}{c}\text { Sakha } \\
104 \\
\end{array}$ & Hybrid 2 & $\begin{array}{c}\text { Sakha } \\
104\end{array}$ & Hybrid 2 & \\
\hline \multirow{3}{*}{$\mathbf{M}_{1}$} & $\mathrm{D}_{1}$ & 0.62 & 0.71 & 0.59 & 0.67 & 0.61 & 0.69 & 0.65 \\
\hline & $\mathrm{D}_{2}$ & 0.65 & 0.72 & 0.61 & 0.72 & 0.63 & 0.72 & 0.68 \\
\hline & Mean & 0.64 & 0.72 & 0.60 & 0.70 & 0.62 & 0.71 & 0.67 \\
\hline \multirow{3}{*}{$\mathbf{M}_{2}$} & $\mathrm{D}_{1}$ & 0.98 & 1.04 & 1.00 & 1.05 & 0.99 & 1.05 & 1.02 \\
\hline & $\mathrm{D}_{2}$ & 1.01 & 1.08 & 1.02 & 1.11 & 1.02 & 1.10 & 1.06 \\
\hline & Mean & 0.99 & 1.06 & 1.01 & 1.08 & 1.01 & 1.08 & 1.04 \\
\hline \multirow{3}{*}{$\mathbf{M}_{3}$} & $\mathrm{D}_{1}$ & 1.06 & 1.18 & 1.09 & 1.16 & 1.08 & 1.17 & 1.12 \\
\hline & $\mathrm{D}_{2}$ & 1.10 & 1.25 & 1.11 & 1.19 & 1.11 & 1.22 & 1.16 \\
\hline & Mean & 1.08 & 1.22 & 1.10 & 1.18 & 1.10 & 1.20 & 1.14 \\
\hline \multirow{2}{*}{$\begin{array}{l}\text { Overall } \\
\text { average }\end{array}$} & $\mathrm{D}_{1}$ & \multicolumn{7}{|c|}{0.93} \\
\hline & $\mathrm{D}_{2}$ & \multicolumn{7}{|c|}{0.97} \\
\hline
\end{tabular}

\section{CONCLUSION AND RECOMMENDATIONS:}

From the previous results it could be concluded that:

a. Over two growing seasons under study, the mean values for plant height, panicle length, 1000 grain weight, grain or straw yield and grain yield productivity per water unit are higher for transplanting method of $\mathrm{M}_{3}$ furrow strips at 80 apart, followed by strip of furrows at $60 \mathrm{~cm}$ as compared with the traditional transplanting method.

b. A similar trend was obtained for irrigation water depth of $8 \mathrm{~cm}$, followed by $6 \mathrm{~cm}$.

c. The greatest mean values for the pervious characters were obtained from rice Hybrid 2 cultivar, followed by Sakha 104 cultivar.

So, it is noteworthy to mention that developing the rice variety are necessary for saving water, increasing rice yield and contributing to living environmental protection. Also, saving irrigation water due to applying furrow strips method does not reduce the rice yield.

\section{REFERENCES:}

Abdel Hafez, S.A. (1982). Effect of irrigation and fertilization on rice yield and soil properties. Ph. D. Thesis, Faculty of Agric., Mansoura Univ., Egypt.

Abdel Hamid, A.M. (2002). Agricultural studies on rice. M. Se. Thesis, Fac. of Agric. at Kafr El-Sheikh, Tanta Univ., Egypt.

Arfat, E.F.A. (2007). Effect of some agronomic practices on hybrid rice. M. Sc. Thesis, Fac. of Agric., Tanta Univ., Egypt.

Fayoum J. Agric. Res. \& Dev., Vol.24, No.2, July, 2010 
Atta, Y.I.M. (2005). Strip transplanting of rice: A new method for increasing water use efficiency under splitting of nitrogen fertilizer. Egypt. J. Appl. Sci., 20 (10B): 501:511.

Biswas, C.R. and B. Bahattacharya (1987). Water management for rice in coastal Salina soil. IRRN, 12: 2 April.

Black, C.A.; D.D. Evans; L.E. Ensminger; J.L. White and F.E. Clark (1965). Methods of Soil Analysis. Am. Soc. of Agron. Inc., Madison, Wisconsin, USA.

De Datta, S.K. (1981). Principles and Practices of Rice Production. John Wiley and Sons, Inc., New York.

El-Hadidi, E.M.; Z.M. El Sirafy; M.A. Ibrahim and E.A. Moursi (2002). Nutrients uptake by rice plant and grain protein content as affected by irrigation depth and rice cultivars grown in Nile Delta. J. Agric. Sci. Mansoura Univ., 27 (8): 5657-5665.

El-Hawary, M.A (2000). Effect of irrigation intervals on yield and yield components of some rice varieties in newly reclaimed soil. Al-Azhar J. Agric Res., 31 (20): 51-62.

El-Khoby W.M. H. (2004). A study on the effect of some cultural practices on rice crop. Ph. D. Thesis, Fac. of Agric., Kafr El-Sheikh Univ., Egypt.

El-Refaee, I.S. (2002). Studies on irrigation systems on some rice cultivars. $\mathrm{Ph}$. D. Thesis, Fac. of Agric., Tanta Univ., Egypt.

El-Wehishy, M.M. and A.G. Abdel Hafez (1998). Response of flooded rice to water deficit. J. Agric. Res. Tanta. Univ., 24 (3): 273-283.

Gee, G.W. and J.W. Bauder 1986. Particle size analysis. In: Methods of Soils Analysi. Part I, Klute, A. (Ed.), Agronomy No. 9.

Mohammed, M.M. (2006). Effect of some agricultural treatments on yield of hybrid. M. Sc. Thesis, Fac. of Agric., Al-Azhar Univ., Egypt.

Snedecor G.W. and W.G. Cochran (1980). Statistical Methods. $7^{\text {th }}$ Edition. Iowa State Univ. Press, Amer. IA.

Walker, W.R. and G.V. Skogerbae (1987). The Theory and Practice of Surface Irrigation. Prentice-Hall, Inc. Englewood Cliffs, N.J.

Zayed B.A.; S.M. Shehata; A.A. Abd Allah and W. M. Elkoby (2007). Growth and grain yield of hybrid and traditional rice as affected by splitting nitrogen under saline soil conditions. J. Agric. Res. Kafer ElShaikh Univ., 33 (4): 787-806.

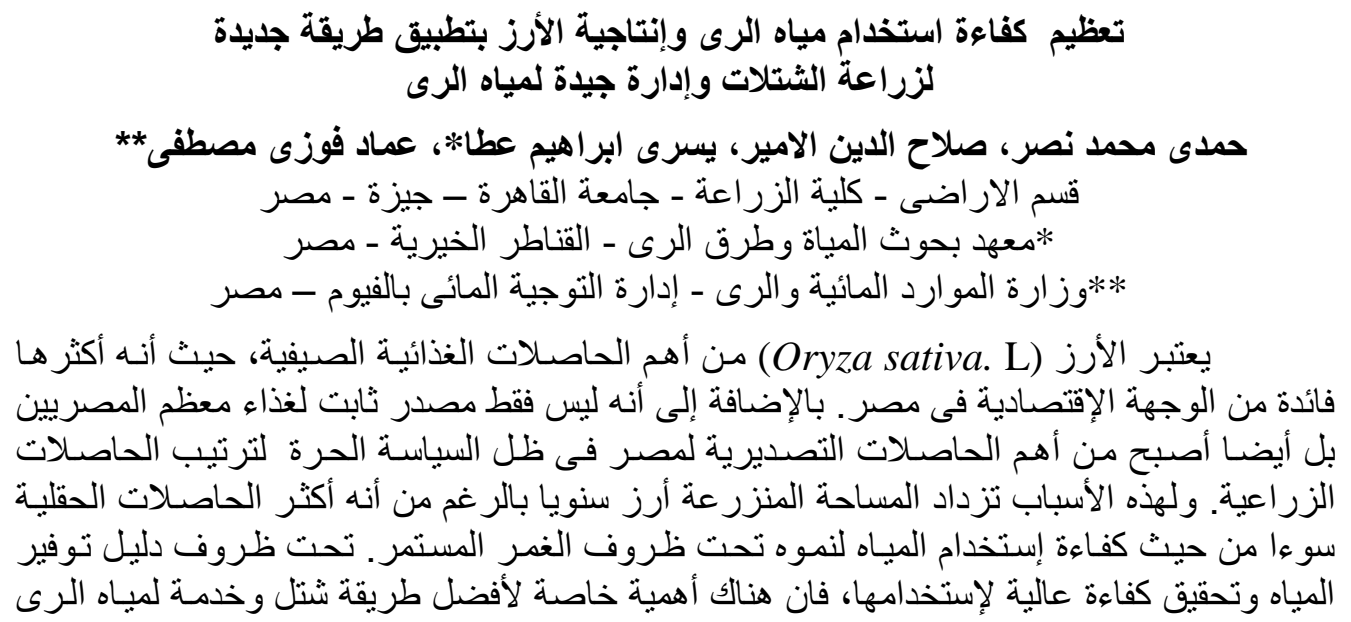

Fayoum J. Agric. Res. \& Dev., Vol.24, No.2, July, 2010 


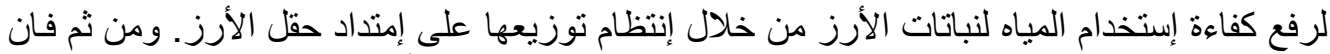

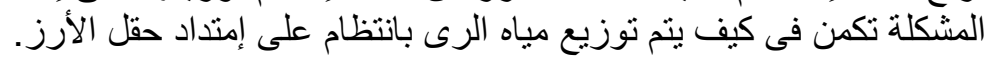

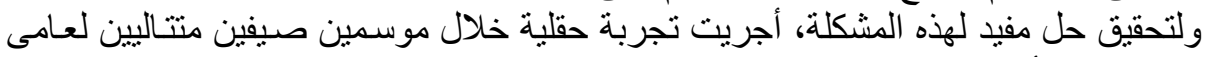

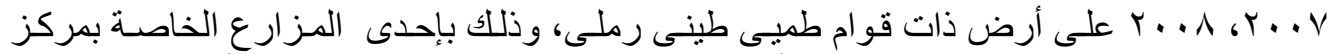

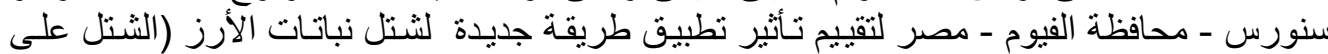

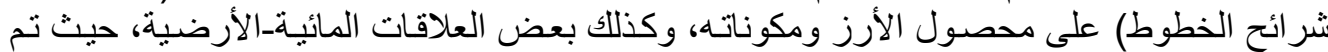

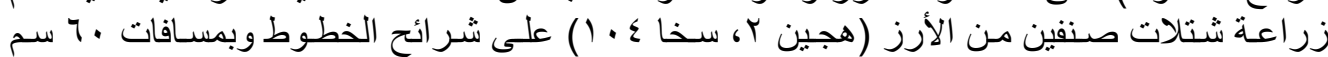
مياه

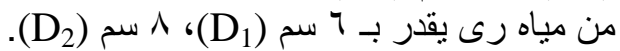

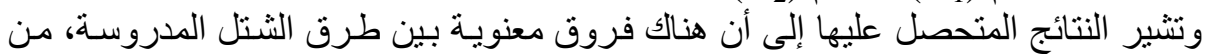

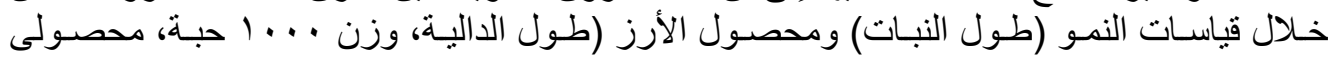

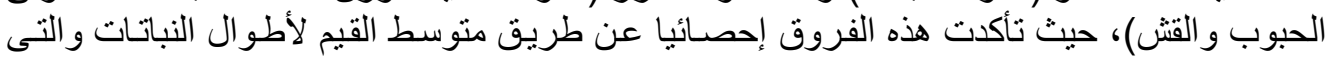

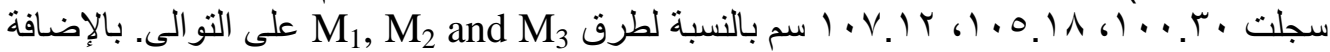

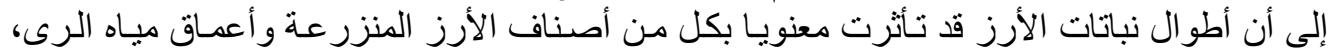

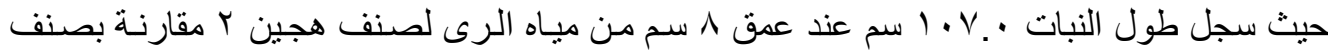

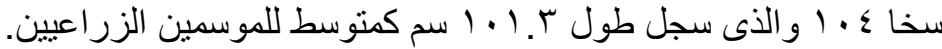

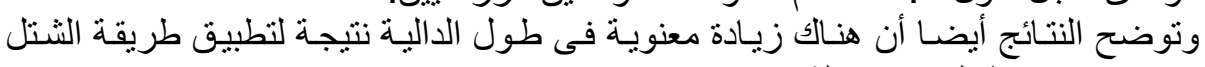

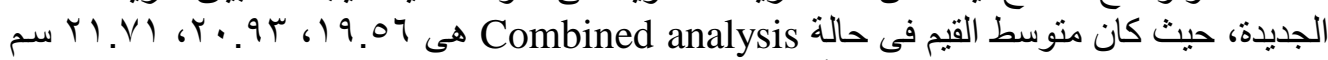
بالنسبة لطرق

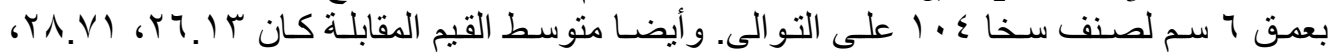

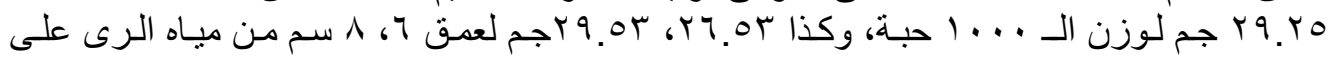

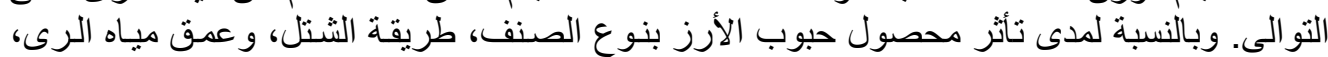

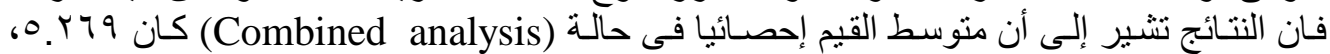

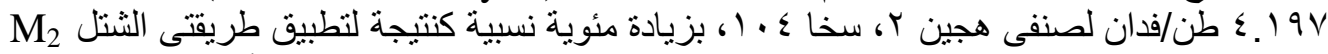

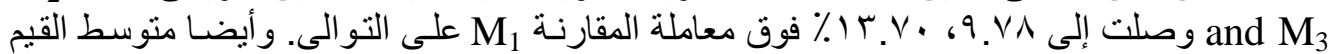

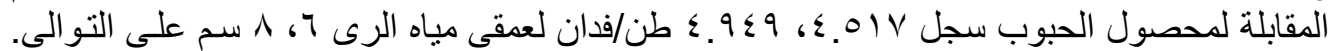

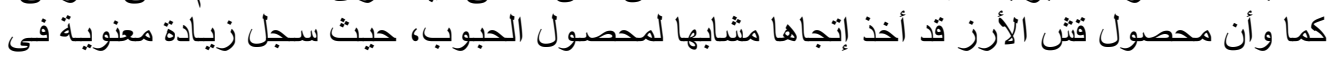

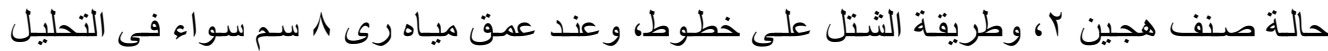

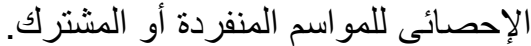

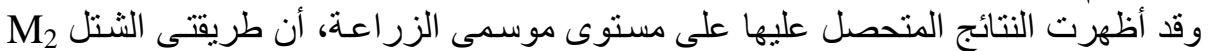
and M3

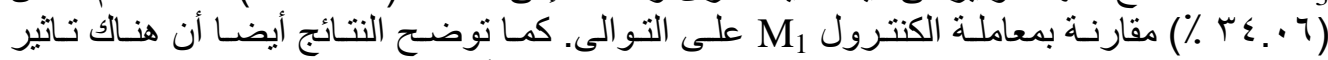

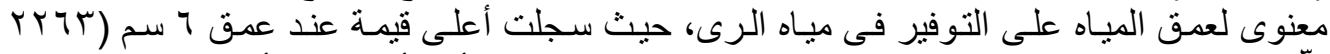

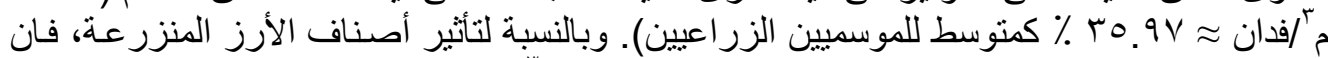

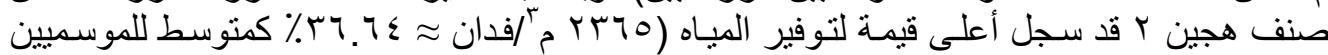

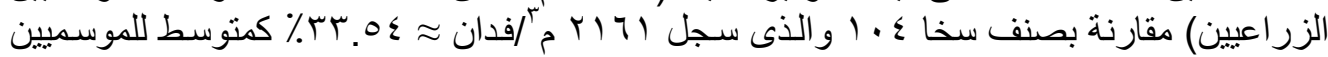

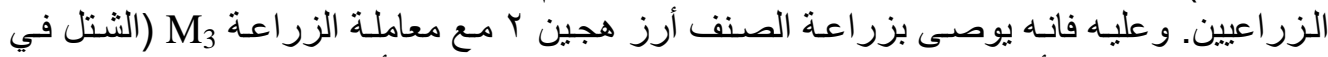

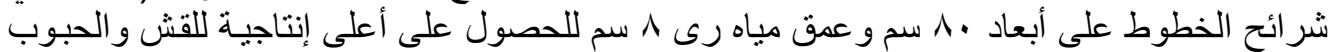

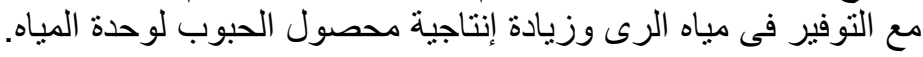

Fayoum J. Agric. Res. \& Dev., Vol.24, No.2, July, 2010 